\title{
Influence of copepod grazing on concentrations of dissolved dimethylsulfoxide and related sulfur compounds in the North Water, northern Baffin Bay
}

\author{
Peter A. Lee ${ }^{1,4}$, Patricia A. Saunders ${ }^{2,5}$, Stephen J. de Mora ${ }^{1,6, *}$, Don Deibel ${ }^{2}$, \\ Maurice Levasseur ${ }^{3}$ \\ ${ }^{1}$ Institut des Sciences de la Mer, Université du Québec à Rimouski, 310 Allée des Ursulines, Rimouski, Québec G5L 3A1, Canada \\ ${ }^{2}$ Ocean Sciences Centre, Memorial University of Newfoundland, St. John's, Newfoundland A1C 5S7, Canada \\ ${ }^{3}$ Institut Maurice-Lamontagne, Ministère des Pêches et des Océans, CP 1000, Mont-Joli, Québec G5H 3Z4, Canada \\ ${ }^{4}$ Present address: Hollings Marine Laboratory, 331 Fort Johnson Road, Charleston, South Carolina 29412, USA \\ ${ }^{5}$ Present address: Department of Biology, Ashland University, Ashland, Ohio 44805, USA \\ ${ }^{6}$ Present address: International Atomic Energy Agency, Marine Environment Laboratory, 4 Quai Antoine 1er, BP 800, \\ 98012 Monaco
}

\begin{abstract}
The impact of copepod grazing on the biogeochemical cycling of dimethylated-sulfur compounds was investigated in the North Water polynya, northern Baffin Bay, during the period 21 April to 24 June 1998. The results show that zooplankton grazing can influence $\mathrm{DMSO}_{\mathrm{d}}$ concentrations in addition to those of DMS and DMSP ${ }_{\mathrm{d}}$. This study is the first to demonstrate this effect for $\mathrm{DMSO}_{\mathrm{d}}$. Weight-specific production rates for $\mathrm{DMSO}_{\mathrm{d}}$ due to the presence of copepods in incubation

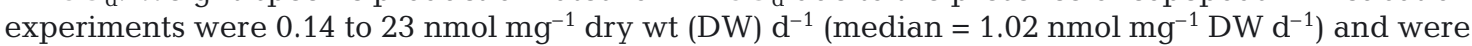
occasionally higher than rates for the production of $\mathrm{DMSP}_{\mathrm{d}}$. Weight-specific production rates for dimethylsulfide were 0.011 to $2 \mathrm{nmol} \mathrm{mg}^{-1} \mathrm{DW} \mathrm{d}^{-1}$ (median $=0.23 \mathrm{nmol} \mathrm{mg}^{-1} \mathrm{DW} \mathrm{d}^{-1}$ ) and for $\mathrm{DMSP}_{\mathrm{d}}$ 0.005 to $6.86 \mathrm{nmol} \mathrm{mg}^{-1} \mathrm{DW} \mathrm{d}{ }^{-1}$ (median $=0.71 \mathrm{nmol} \mathrm{mg}^{-1} \mathrm{DW} \mathrm{d}^{-1}$ ). In comparison, the volumetric and individual-normalized production rates for DMS and $\mathrm{DMSP}_{\mathrm{d}}$, which were used to derive weightspecific production rates for these compounds, were similar to published results. The influence of copepod grazing on the production rates of DMS and $\mathrm{DMSP}_{\mathrm{d}}$ was statistically significant in more than $85 \%$ of the incubation experiments conducted, but in fewer than $50 \%$ of the incubations for $\mathrm{DMSO}_{\mathrm{d}}$. These results suggest that the impact of copepod grazing might be less important for the biogeochemical cycling of DMSO than that of DMS and DMSP. Analysis of the data indicates that grazing may influence the release of DMSO and DMSP in different ways. A secondary objective of the study was to assess the potential role of copepod grazing on in situ level of DMS, DMSP ${ }_{d}$ and $\mathrm{DMSO}_{\mathrm{d}}$ in the North Water. Weight-specific production rates were used to calculate in situ production rates, which ranged from 0.002 to $21.7 \mathrm{nmol} \mathrm{m}^{-3} \mathrm{~d}^{-1}$ for DMS, from 0.001 to $85.8 \mathrm{nmol} \mathrm{m}^{-3} \mathrm{~d}^{-1}$ for DMSP ${ }_{\mathrm{d}}$, and from 0.003 to $184 \mathrm{nmol} \mathrm{m}^{-3} \mathrm{~d}^{-1}$ for $\mathrm{DMSO}_{\mathrm{d}}$. Comparison of these results with the average concentrations of DMS, DMSP ${ }_{d}$ and $\mathrm{DMSO}_{\mathrm{d}}$ in the water column of the polynya indicates that copepod grazing was a minor mechanism in the release of these compounds in the North Water.
\end{abstract}

KEY WORDS: Arctic $\cdot$ Biogeochemical cycles · Copepods · Dimethylsulfide $\cdot$ Dimethylsulfoniopropionate $\cdot$ Dimethylsulfoxide $\cdot$ Grazing $\cdot$ Polynya

\section{INTRODUCTION}

Dimethylsulfide (DMS) is a volatile compound of principally oceanic origin that may influence planetary climate by altering the global radiation balance (Charl- son et al. 1987), the hydrological cycle (Mészáros 1988), and by increasing precipitation acidity in remote regions (Savoie \& Prospero 1989). The transfer of DMS from the ocean to the atmosphere can represent up to $90 \%$ of the total sulfur transferred and up to 
half of the global budget for biogenic sulfur entering the troposphere (Charlson et al. 1987, Andreae 1990, Malin et al. 1992). The precursor to DMS is generally assumed to be DMSP, a cryoprotective and osmoregulatory compound found in many micro- and macroalgae (Vairavamurthy et al. 1985, Dickson \& Kirst 1986, Kirst et al. 1991). A variety of factors are responsible for the release and transformation of DMSP into DMS, including cell senescence, water-column bacteria, phytoplankton-derived DMSP-lyase and viruses (Turner et al. 1988, Malin et al. 1992, Bratbak et al. 1995, Hill et al. 1998, Wilson et al. 1998).

Another important factor influencing the formation of DMS and DMSP ${ }_{d}$ is zooplankton grazing, although the magnitude and nature of the changes induced by grazing have been shown to be highly variable. The potential effects of zooplankton grazing on the production of DMS and DMSP have been demonstrated both in the laboratory and in the field. In phytoplankton cultures, the presence of copepods resulted in more than a 20-fold increase in DMS production rates (Dacey \& Wakeham 1986). In sub-arctic waters, Levasseur et al. (1994) observed that concentrations of (DMS + DMSP were up to 25 times greater when suspension-feeding pteropods were present. DMS concentrations were also found to be positively correlated with copepod biomass in the Baltic Sea (Leck et al. 1990). Krill have been shown to have a significant impact on the removal of $\mathrm{DMSP}_{\mathrm{p}}$ and the production of DMS in waters surrounding the Antarctic Peninsula (Daly \& DiTullio 1996). Furthermore, Daly \& DiTullio (1996) found low, but measurable amounts of $\mathrm{DMSP}_{\mathrm{p}}$ in deep-water sediment traps, leading them to conclude that fecal pellets might be an important sink for DMSP.

More equivocal results have also been published. No relationship was observed between mesozooplankton abundance and DMS distribution in the Gulf of Maine (Matrai \& Keller 1993). The formation of DMS could not be measured by Kwint et al. (1996) in laboratory experiments involving copepods, although they did observe that most DMSP was repackaged into fecal pellets with a slight increase in $\mathrm{DMSP}_{\mathrm{d}}$ concentrations. In the Gulf of St. Lawrence, Cantin et al. (1996) could find no significant correlation between mesozooplankton abundance and the distribution of DMS or $\mathrm{DMSP}_{\mathrm{d}}$. Furthermore, after extrapolating accumulation rates measured during incubation experiments to field conditions, they concluded that mesozooplankton grazing played only a minor role in the production of DMS and $\mathrm{DMSP}_{\mathrm{d}}$ in the Gulf of St. Lawrence. Such inconsistencies in the impact of grazing on DMS and DMSP Cantin et al. (1996) to speculate that the effect most probably varied in response to temporal and spatial changes in the abundance and type of phytoplankton encountered by zooplankton. Several laboratory- based studies have shown that grazers may preferentially select non-DMS-producing phytoplankton when a mixture of prey is available (Wolfe \& Steinke 1996, Wolfe et al. 1997).

With respect to the biogeochemical cycling of DMSO, it is conventionally believed that $\mathrm{DMSO}_{\mathrm{d}}$ in aquatic environments originates from the photochemical and microbial oxidation of DMS (Brimblecombe \& Shooter 1986, Zeyer et al. 1987). Yet, much of the marine sulfur cycle involving DMSO, particularly the origins of DMSO, remains poorly understood (Malin \& Kirst 1997). Some recent studies have shown that DMSO is present in phytoplankton (Simó et al. 1998, Lee et al. 1999, 2001). At the time this study was conducted in the North Water region, Bouillon et al. (2002) found relatively high levels of $\mathrm{DMSO}_{\mathrm{p}}$. The combined findings of the studies by Simó et al. (1998), Lee et al. (2001) and Bouillon et al. (2002) suggest that $\mathrm{DMSO}_{\mathrm{p}}$ is present in a wide variety of phytoplankton species including those that are not recognized as DMSP producers. It has been argued that zooplankton might also release intracellular DMSO during grazing, thereby influencing $\mathrm{DMSO}_{\mathrm{d}}$ concentrations in the same way that grazing influences DMS and DMSP ${ }_{d}$ concentrations (Lee \& de Mora 1999). Currently, no studies have examined the impact of zooplankton grazing on concentrations of $\mathrm{DMSO}_{\mathrm{d}}$. The primary objective of this investigation was to determine if $\mathrm{DMSO}_{\mathrm{d}}$ concentrations could be affected by copepod grazing. The secondary goal of this study was to calculate the potential impact of copepod grazing on in situ concentrations of DMS, $\mathrm{DMSP}_{\mathrm{d}}$ and $\mathrm{DMSO}_{\mathrm{d}}$ in the North Water, northern Baffin Bay.

\section{MATERIALS AND METHODS}

Study area. The experiments were carried out as part of the International North Water Polynya Study aboard the Canadian Coast Guard ice-breaker CCGS 'Pierre Radisson' during April, May and June 1998. The International North Water Polynya Study was a multiyear, multidisciplinary study aimed at examining the physical, chemical and biological components of the North Water ecosystem and elucidating the linkages between them (Deming et al. 2002). Stations where dimethylated-sulfur (DMS, DMSP ${ }_{d}, \mathrm{DMSO}_{\mathrm{d}}$ ) measurements were made in conjunction with copepod grazing experiments are illustrated in Fig. 1. The North Water ( $\sim 75$ to $79^{\circ} \mathrm{N}, \sim 71$ to $78^{\circ} \mathrm{W}$, Fig. 1$)$ is a large, recurrent polynya in northern Baffin Bay (Fig. 1) that is believed to be one of the most productive areas above the Arctic Circle (Stirling 1980, Lewis et al. 1996, Klein et al. 2002). During winter and spring, strong northerly winds drive ice southward in the western portion of the polynya. Formation of an ice 


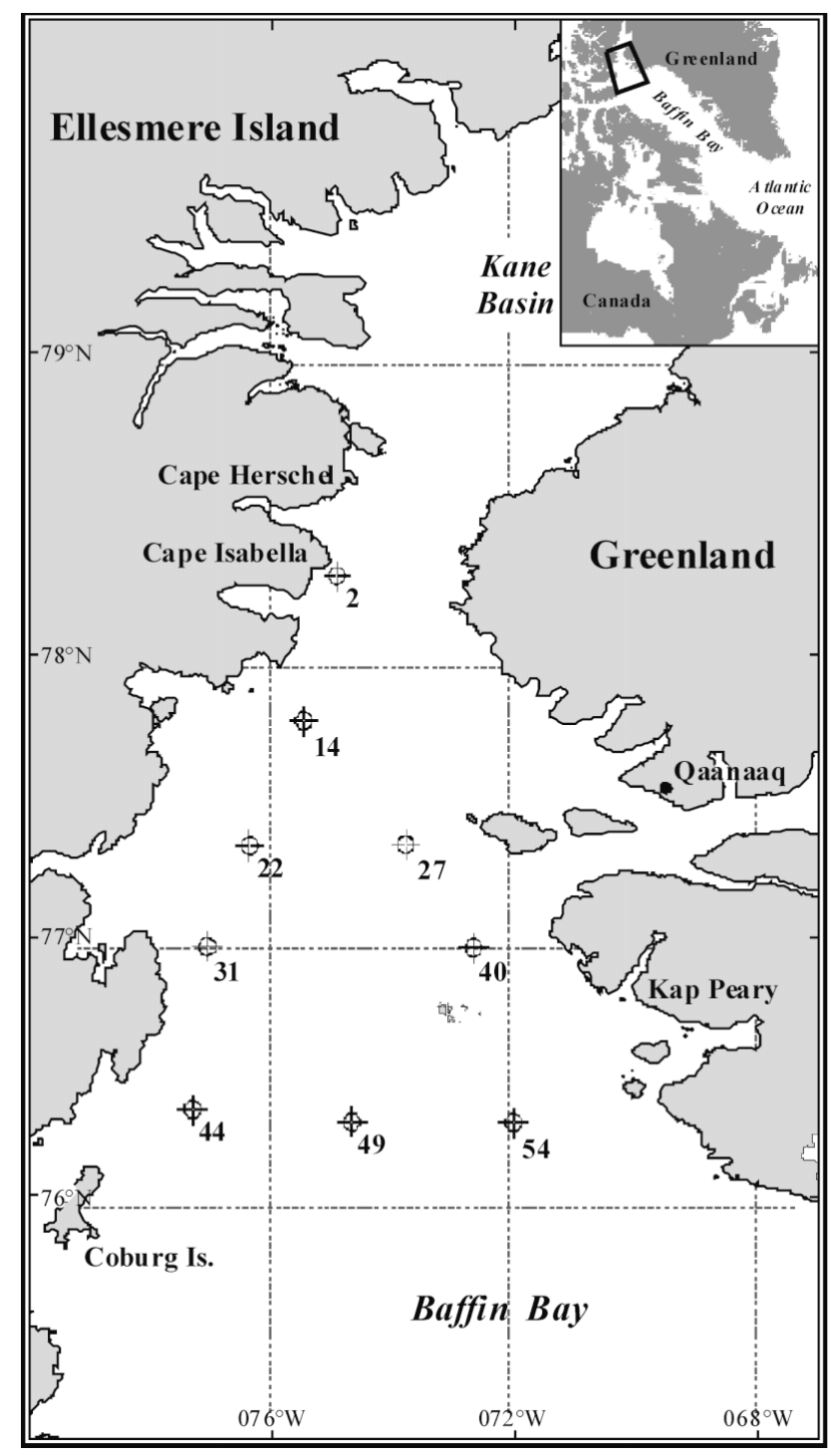

Fig. 1. Map showing general location of North Water region in northern Baffin Bay and positions of stations where incubations were conducted

bridge in Kane Basin prevents ice from entering the polynya from the north. However, upwelling near the Greenland coast can bring relatively warm water to the base of the turbulent surface layer, where it is entrained via brine-driven convection that results from ice growth. The resulting flux of sensible heat slows ice growth, thereby contributing to the maintenance of the polynya during late spring, but it is not large enough to generate the polynya. The southern limit of the polynya lies around $76^{\circ} 30^{\prime}$ to $75^{\circ} 30^{\prime} \mathrm{N}$ between January and May and between $\sim 75^{\circ}$ and $\sim 74^{\circ} \mathrm{N}$ by June. By July, the polynya has reached its maximum extent. At this time, the North Water finally disappears when the ice tongue that separates it from the rest of Baffin Bay melts. Reviews of our current understanding of the oceanographic and meteorological factors that lead to the formation and maintenance of the North Water polynya can be found elsewhere (Melling et al. 2001, Bâcle et al. 2002, Ingram et al. 2002). Furthermore, studies that deal with biological and chemical aspects of the North Water are available elsewhere (Lee et al. 2001, Bouillon et al. 2002, Klein et al. 2002, Lovejoy et al. 2002, Miller et al. 2002, Odate et al. 2002, Tremblay et al. 2002).

Grazing experiments. Water-column sampling was performed using a General Oceanics rosette system equipped with $24 \times 101$ Brookes Ocean Technology sample bottles. A Falmouth Scientific Instrument CTD (FSI-ICTD) was mounted in the center of the rosette, allowing real-time monitoring and acquisition of oceanographic data. Water for the experiments was obtained using a single rosette cast at 1 or 2 depths in the upper mixed layer. One of these depths was within the chlorophyll maximum, which was determined from the fluorescence profile during the downcast. It should be noted that for the 2 experiments carried out in April, there was very little accumulation of phytoplankton biomass at any depth within the water column. Samples from each 101 bottle were transferred via silicon tubing to a 10 l polyethylene cubitainer and transported to a darkened room that was maintained at approximately $0^{\circ} \mathrm{C}$.

Copepods for the experiments were collected with vertical tows of a $200 \mu \mathrm{m}$ Nitex mesh plankton net ( $1 \mathrm{~m}^{2}$ or $1 \mathrm{~m}$ diam. $\times 6 \mathrm{~m}$ length). The cod-end was closed except for 1 or 2 small drainage windows (approx. $5 \mathrm{~cm}^{2}$ ) near the top of the cylinder. To avoid damaging the copepods, the net was retrieved at a relatively low rate of 0.3 to $0.5 \mathrm{~m} \mathrm{~s}^{-1}$ and was not rinsed. The cod-end was removed immediately and its contents gently diluted into 201 of surface seawater. A $300 \mu \mathrm{m}$-mesh sieve cup was then used to transfer a sufficient number of copepods into 201 of experimental water stored in a cooler. The cooler was transported to the cold room, where the copepods were allowed to acclimate to their new environment for 2 to $24 \mathrm{~h}$. This step provided an opportunity to check their condition.

Working in the cold room with a minimum of light, grazing experiments were set up in 41 polycarbonate bottles that were subsequently attached to a plankton wheel. For each depth tested, 2 control (no copepods added) and 3 treatment (copepods added) bottles were used. Additional information on some of the experimental conditions, such as copepod concentrations and body size, are given in Table 1 . The water in the cubitainers were gently mixed by inversion, then gravitytransferred via silicon tubing into the $4 \mathrm{l}$ experimental bottles and an equal number of initial $\left(t_{0}\right)$ sampling bottles. Control bottles were filled completely, sealed 
Table 1. Parameters describing the copepod assemblages added to treatment incubation containers. L: large; S: small; Depth range: range over which copepods collected; Avg. no. (SD) copepods: avarage no. of copepods in incubations; DW: dry wt; CL: carapace length; Dominant groups: numerically dominant copepod groups; met6f: Metridia longa VI female; met5: M. longa $\mathrm{V}_{i}$ met4: M. longa IV; ch6f: Calanus hyperboreus VI female; ch5: C. hyperboreus $\overline{\mathrm{V}_{i}}$ ch4: C. hyperboreus IV; cfg6f: $\bar{C}$. finmarchicus and C. glacialis VI female; $\mathrm{cfg} 5$ : C. finmarchicus and C. glacialis V; cfg4: C. finmarchicus and C. glacialis IV $;$ c13: Calanus I, II and III (3 species); pcal6f: Pseudocalanus sp. VI female; pcal6m: Pseudocalanus sp. VI male

\begin{tabular}{|c|c|c|c|c|c|c|c|}
\hline Stn no. & $\begin{array}{l}\text { Date } \\
(1998)\end{array}$ & $\begin{array}{l}\text { Sampling depth } \\
(\mathrm{m})\end{array}$ & $\begin{array}{l}\text { Depth range } \\
(\mathrm{m})\end{array}$ & $\begin{array}{l}\text { Avg. no. (SD) } \\
\text { copepods } 1^{-1}\end{array}$ & $\begin{array}{l}\text { Avg. (SD) DW } \\
\quad\left(\mathrm{mg} \mathrm{l}^{-1}\right)\end{array}$ & $\begin{array}{l}\text { Avg. (SD) CL } \\
\text { (mm) }\end{array}$ & Dominant groups \\
\hline 44 & 21-23 Apr & $\begin{array}{l}50(\mathrm{~L}) \\
50(\mathrm{~S})\end{array}$ & $\begin{array}{l}0-385 \\
0-385\end{array}$ & $\begin{array}{l}13.6(1.3) \\
49.3(1.5)\end{array}$ & $\begin{array}{l}7.7(0.9) \\
5.9(0.7)\end{array}$ & $\begin{array}{l}3.2(0.1) \\
1.8(0.1)\end{array}$ & 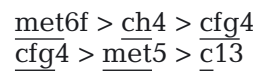 \\
\hline 27 & 27-28 Apr & $\begin{array}{r}35 \\
110\end{array}$ & $\begin{array}{c}0-75 \\
78-150\end{array}$ & $\begin{array}{l}16.1(3.7) \\
48.3(9.0)\end{array}$ & $\begin{array}{r}9.8(3.5) \\
13.7(1.6)\end{array}$ & $\begin{array}{l}3.8(0.2) \\
2.6(0.2)\end{array}$ & 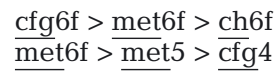 \\
\hline 54 & 25-27 May & $\begin{array}{l}15 \\
75\end{array}$ & $\begin{array}{c}0-50 \\
50-150\end{array}$ & $\begin{array}{l}12(2.8) \\
6.8\end{array}$ & $\begin{array}{r}11.0(0.7) \\
2.2(1.2)\end{array}$ & $\begin{array}{l}4.1(0.5) \\
2.5(0.3)\end{array}$ & $\begin{array}{l}\operatorname{ch} 5>\operatorname{ch} 6 \mathrm{f}>\mathrm{c} 13 \\
\underline{\operatorname{met}} 5>\underline{m e t} 6 \overline{\mathrm{f}}>\operatorname{met} 4\end{array}$ \\
\hline 54 & 05-06 Jun & 11 & $0-50$ & $8.4(2.0)$ & $7.4(1.4)$ & $3.9(0.4)$ & $\underline{\operatorname{met}} 6 \mathrm{f}>\underline{\operatorname{ch} 5}>\underline{\operatorname{ch} 6 f}$ \\
\hline 49 & 05-06 Jun & 20 & $0-50$ & $9.5(2.0)$ & $3.8(1.5)$ & $2.6(0.4)$ & $\underline{\mathrm{c}} 13>\underline{\mathrm{ch} 5}>\underline{\mathrm{cfg} 5}$ \\
\hline 2 & 07-09 Jun & $\begin{array}{l}37(\mathrm{~L}) \\
37(\mathrm{~S})\end{array}$ & $\begin{array}{l}0-50 \\
0-50\end{array}$ & $\begin{array}{l}4.9(0.5) \\
8.5\end{array}$ & $\begin{array}{l}4.3(0.8) \\
0.1(0.1)\end{array}$ & $\begin{array}{l}3.8(0.3) \\
1.0(0.1)\end{array}$ & $\begin{array}{l}\text { ch6f }>\text { met6f }>\text { ch5 } \\
\text { c13 }>\text { pcal6f }\end{array}$ \\
\hline 14 & 10-12 Jun & 15 & $0-55$ & $9.8(9.5)$ & $0.6(0.2)$ & $1.4(0.4)$ & c13 > pcal $6 m$ \\
\hline 22 & 14-16 Jun & 15 & $0-50$ & $8.0(2.0)$ & $0.4(0.2)$ & $1.4(0.1)$ & $\underline{\mathrm{c}} 13>\underline{\text { pcal6f }}$ \\
\hline 31 & 15-17 Jun & $\begin{array}{l}15 \\
75\end{array}$ & $\begin{array}{c}0-50 \\
50-150\end{array}$ & $\begin{array}{l}7.0(0.3) \\
4.5(1.0)\end{array}$ & $\begin{array}{l}0.5(0.1) \\
2.0(0.5)\end{array}$ & $\begin{array}{l}1.6(0.1) \\
2.8(0.1)\end{array}$ & $\begin{array}{l}\text { c13 } \\
\text { met6f }>\text { c13 }>\text { cfg5 } 5\end{array}$ \\
\hline 40 & 19-20 Jun & $\begin{array}{l}15 \\
80\end{array}$ & $\begin{array}{l}0-20 \\
0-120\end{array}$ & $\begin{array}{l}5.0(0.8) \\
4.3(0.3)\end{array}$ & $\begin{array}{l}1.4(0.2) \\
3.3(1.1)\end{array}$ & $\begin{array}{l}2.3(0.2) \\
3.2(0.2)\end{array}$ & $\begin{array}{l}\overline{\mathrm{c} 13}>\operatorname{cfg} 5>\overline{\mathrm{cfg} 4} \\
\underline{\mathrm{cfg} 5}>\underline{\mathrm{ch} 5}\end{array}$ \\
\hline 54 & 22-24 Jun & 35 & $0-75$ & $7.0(1.0)$ & $4.0(1.4)$ & $3.2(0.4)$ & $\overline{\mathrm{c} 13}>\overline{\operatorname{ch} 5}>\operatorname{cfg} 5$ \\
\hline
\end{tabular}

with parafilm, and capped. Treatment bottles were filled within 100 to $200 \mathrm{ml}$ of the top. The copepods were then slowly added and the bottles topped off with water, sealed and capped as above. Copepods were collected from the incubation cooler with a $300 \mu \mathrm{m}$ mesh Nitex sieve and a wide-bore pipette. For 2 experiments, treatments were separated into 'large' and 'small' copepod assemblages (Table 1) using a sieve made of nylon window screen with $1300 \times 1050 \mu \mathrm{m}$ rectangular openings. The copepods were inspected, counted against a small backlight, and then gently released into bottles. The time for $t_{0}$ was recorded as the hour and minute when each experimental bottle was sealed and capped.

The experimental bottles were incubated in the dark at approx. $0^{\circ} \mathrm{C}$ and were rotated continuously on a plankton wheel for 24 or $48 \mathrm{~h}$. At the end of the incubation, pairs of bottles were removed and final time $\left(t_{\mathrm{f}}\right)$ samples were collected for dimethylated-sulfur chemistry and pigment analysis. As with the preparation of the experimental bottles, sampling was carried out using gravity and silicon tubing. However, in this case, a piece of $300 \mu \mathrm{m}$ Nitex mesh was attached to the inflow end of the tubing to exclude the treatment individuals from the final subsamples. The final time $\left(t_{\mathrm{f}}\right)$ was recorded as the hour and minute when the caps were removed and sample collection began. Using Wheaton serum bottles sealed with butyl rubber stoppers and aluminium caps, $50 \mathrm{ml}$ aliquots were taken from the $t_{0}$ and $t_{\mathrm{f}}$ samples for dimethylated-sulfur compound analyses. Samples were stored in the dark at $-1^{\circ} \mathrm{C}$ until processing. Samples collected for chlorophyll a (chl a) and phaeopigments were filtered onto $25 \mathrm{~mm} \mathrm{GF} / \mathrm{F}$ filters and stored at $-80^{\circ} \mathrm{C}$ until postcruise processing.

In situ copepod biomass. Quantitative zooplankton samples were collected by stratified vertical tows of a $6 \mathrm{~m}$ long Nitex-mesh plankton net $\left(200 \mu \mathrm{m} \times 1 \mathrm{~m}^{2}\right.$ or $300 \mu \mathrm{m} \times 1 \mathrm{~m}$ diam.). Stratified net tows represented surface or mid-depth strata (Table 1). On each occasion, the net was retrieved at 0.3 to $0.5 \mathrm{~m} \mathrm{~s}^{-1}$. The samples were then rinsed into the cod-end, concentrated, and preserved in $4 \%$ formalin. A Motoda box-splitter or Hensen-Stemple pipette was used to make quantitative fractions of the original sample. The copepods were sorted by species and stage. In situ abundance was calculated using tow-volume estimates determined from net dimensions and flow-meter values. In situ biomass was calculated using the same empirical model that was applied to the quantification of the experimental treatments (see later subsection on 'Analysis of biological samples').

Analyses for DMS, DMSP $\mathbf{d}_{\mathbf{d}}$ and $\mathbf{D M S O}_{\mathbf{d}}$. Once all $t_{0}$ or $t_{\mathrm{f}}$ samples had been prepared, the samples were analyzed immediately for DMS (see below). After DMS analysis, the samples were filtered through Whatman GF/F filters to remove any particulate material. Then, $2 \mathrm{ml}$ of $5 \mathrm{~mol} \mathrm{l}^{-1}$ sodium hydroxide was added to a $48 \mathrm{ml}$ 
aliquot of the filtered sample to hydrolyze $\mathrm{DMSP}_{\mathrm{d}}$ to DMS (White 1982). The samples were stored for 24 to $48 \mathrm{~h}$ and then reanalyzed for DMS. Selected samples were then analyzed for $\mathrm{DMSO}_{\mathrm{d}}$ using the sodium borohydride-reduction technique (Simó et al. 1996). The pH of the DMSP-free sample was adjusted by the addition of $2 \mathrm{ml}$ of $10 \%$ hydrochloric acid, and the sample was sparged for $10 \mathrm{~min}$. The gas flow was then stopped, and a pellet of sodium borohydride $(0.11 \mathrm{~g}$ dissolved in $5 \mathrm{ml}$ Milli-Q water) was added followed by a further $4 \mathrm{ml}$ of $10 \% \mathrm{HCl}$. Once the effervescence had subsided, the sample was sparged for an additional $15 \mathrm{~min}$. During the sparging sequence, the DMS was collected from the gas stream and analyzed at the end of the sequence. Aliquots of all samples were acidified to $\mathrm{pH} 1$ and stored at $-80^{\circ} \mathrm{C}$ (as outlined by Andreae 1980) until they could be reanalyzed for $\mathrm{DMSO}_{\mathrm{d}}$ in a shore-based laboratory. Results from the analysis of the stored samples were compared with the samples analyzed during the cruise. The difference between the 2 sets of results was less than the analytical error.

During the cruise, analyses for the dissolved dimethylated-sulfur species were carried out using a purge-and-trap preconcentration technique and a gas chromatograph equipped with a sulfur-specific flame photometric detector (Varian 3400 GC-FPD). For analyses carried out in the shore-based laboratory, a gas chromatograph fitted with a pulsed-flame photo- metric detector (Varian 3400 GC-PFPD) was employed. Additional details for these systems can be found elsewhere (Lee \& de Mora 1996, Lee et al. 1999; and references therein). In brief, the sample was sparged with high-purity nitrogen, and the resulting gas stream was passed through a $\mathrm{K}_{2} \mathrm{CO}_{3}$ scrubber tube to remove any water and then through a collection tube containing Molecular Sieve 5A (Supelco). Once sparging was complete, the collection tube was transferred to a ballistic heater unit and the sample was injected into the GC via a 6-port Rheodyne valve. The detection limit for DMS was $0.04 \mathrm{nmol} \mathrm{l}^{-1}$ with coefficients of variation of 9,11 and $15 \%$ for the analyses of DMS, DMSP and DMSO, respectively.

Analyses of biological samples. Experimental copepod samples were thawed and enumerated by species and stage. The carapace length of most individuals was measured to the nearest $0.04 \mathrm{~mm}$. An empirical regression model that included individuals with lengths of 1.9 to $7.2 \mathrm{~mm}$ was used to estimate the biomass in all samples of North Water copepods (P.A.S. and D.D. unpubl. data; $\mathrm{DW}=\mu \mathrm{g}$ dry weight ind. ${ }^{-1}$, length $\left.=\mathrm{mm}, \mathrm{r}^{2}=0.80, \mathrm{n}=65\right)$.

$$
\begin{aligned}
\ln (\mathrm{DW})= & -4.85( \pm 0.598)+4.54( \pm 0.922) \times \ln (\text { length }) \\
& -0.882( \pm 0.340) \times(\ln [\text { length }])^{2}
\end{aligned}
$$

Total copepod dry weight per liter in the experiments is reported as the arithmetic average for each set

Table 2. Average initial concentrations of chlorophyll a (chl a), DMS, $\mathrm{DMSP}_{\mathrm{d}}$ and $\mathrm{DMSO}_{\mathrm{d}}$ in treatment containers, and average water-column concentrations of $\mathrm{DMSP}_{\mathrm{p}}$ and $\mathrm{DMSO}_{\mathrm{p}}$ at each of the stations where water was collected for incubation experi-

\begin{tabular}{|c|c|c|c|c|c|c|c|c|}
\hline \multirow[t]{2}{*}{ Stn no. } & \multirow[t]{2}{*}{ Date } & \multirow{2}{*}{$\begin{array}{l}\text { Sampling } \\
\text { depth } \\
\text { (m) }\end{array}$} & \multicolumn{4}{|c|}{ Initial $\left(t_{0}\right)$ conc. in treatments } & \multicolumn{2}{|c|}{ Water-column conc. } \\
\hline & & & $\begin{array}{c}\text { Chl } a \\
\left(\mu g l^{-1}\right)\end{array}$ & $\begin{array}{c}\text { DMS } \\
\left(\mathrm{nmol} \mathrm{l}^{-1}\right)\end{array}$ & $\begin{array}{c}\mathrm{DMSP}_{\mathrm{d}} \\
\left(\mathrm{nmol} \mathrm{l}^{-1}\right)\end{array}$ & $\begin{array}{c}\mathrm{DMSO}_{\mathrm{d}} \\
\left(\mathrm{nmol} \mathrm{l}^{-1}\right)\end{array}$ & $\begin{array}{c}\operatorname{DMSP}_{\mathrm{p}} \\
\left(\mathrm{nmol} \mathrm{l}^{-1}\right)\end{array}$ & $\begin{array}{l}\mathrm{DMSO}_{\mathrm{p}} \\
\left(\mathrm{nmol} \mathrm{l}^{-1}\right)\end{array}$ \\
\hline 44 & 21-23 Apr & $\begin{array}{l}50(\mathrm{l}) \\
50(\mathrm{~s})\end{array}$ & $\begin{array}{l}0.05^{\mathrm{a}} \\
0.05^{\mathrm{a}}\end{array}$ & $\begin{array}{l}0 \\
0\end{array}$ & $\begin{array}{l}0.18 \\
0.13\end{array}$ & $\begin{array}{l}35.1 \\
35.8\end{array}$ & $\begin{array}{l}\text { nd } \\
\text { nd }\end{array}$ & $\begin{array}{l}\text { nd } \\
\text { nd }\end{array}$ \\
\hline 27 & $27-28$ Apr & $\begin{array}{r}35 \\
110\end{array}$ & $\begin{array}{l}0.39^{\mathrm{a}, \mathrm{b}} \\
0.01^{\mathrm{a}}\end{array}$ & $\begin{array}{l}0.14 \\
0.14\end{array}$ & $\begin{array}{l}0.32 \\
0.33\end{array}$ & $\begin{array}{l}47.2 \\
47.1\end{array}$ & $\begin{array}{l}0.39 \\
0.022\end{array}$ & $\begin{array}{l}0.28 \\
0.021\end{array}$ \\
\hline 54 & 25-27 May & $\begin{array}{l}15 \\
75\end{array}$ & $\begin{array}{r}13.5^{\mathrm{b}, \mathrm{c}} \\
1.47^{\mathrm{c}}\end{array}$ & $\begin{array}{l}1.47 \\
0.4\end{array}$ & $\begin{array}{l}1.19 \\
1.29\end{array}$ & $\begin{array}{l}53.1 \\
51.2\end{array}$ & $\begin{array}{l}0.4 \\
1.35\end{array}$ & $\begin{array}{l}0.63 \\
2.99\end{array}$ \\
\hline 54 & 05-06 Jun & 11 & $4.2^{\mathrm{c}}$ & 0.53 & 7.95 & 41 & 1.13 & 8.68 \\
\hline 49 & 05-06 Jun & 20 & $10.3^{\mathrm{c}}$ & 0.58 & 2.1 & 62.5 & 0.31 & 5.08 \\
\hline 2 & 07-09 Jun & $\begin{array}{l}37(1) \\
37(\mathrm{~s})\end{array}$ & $\begin{array}{l}0.31^{\mathrm{a}} \\
0.31^{\mathrm{a}}\end{array}$ & $\begin{array}{l}0 \\
0\end{array}$ & $\begin{array}{l}0.05 \\
0.05\end{array}$ & $\begin{array}{l}54.5 \\
50.5\end{array}$ & $\begin{array}{l}0.3 \\
0.3\end{array}$ & $\begin{array}{l}0.22 \\
0.22\end{array}$ \\
\hline 14 & 10-12 Jun & 15 & $7.56^{\mathrm{b}, \mathrm{c}}$ & 0.34 & 2.67 & 71.5 & 0.16 & 0.73 \\
\hline 22 & 14-16 Jun & 15 & $2.89^{c}$ & 0 & 0.29 & 58.3 & 0.25 & 2.45 \\
\hline 31 & 15-17 Jun & $\begin{array}{l}15 \\
75\end{array}$ & $\begin{array}{l}4.62^{\mathrm{c}} \\
2.07^{\mathrm{b}, \mathrm{c}}\end{array}$ & $\begin{array}{l}0 \\
0\end{array}$ & $\begin{array}{l}0.27 \\
0.22\end{array}$ & $\begin{array}{l}61.5 \\
60.1\end{array}$ & $\begin{array}{l}0.15 \\
0.075\end{array}$ & $\begin{array}{l}0.14 \\
2.72\end{array}$ \\
\hline 40 & 19-20 Jun & $\begin{array}{l}15 \\
80\end{array}$ & $\begin{array}{c}10.3^{\mathrm{b}, \mathrm{c}} \\
1.2^{\mathrm{c}}\end{array}$ & $\begin{array}{l}0.23 \\
0.23\end{array}$ & $\begin{array}{l}2.15 \\
1.83\end{array}$ & $\begin{array}{l}58.3 \\
55.6\end{array}$ & $\begin{array}{l}0.4 \\
0.34\end{array}$ & $\begin{array}{l}2.57 \\
1.83\end{array}$ \\
\hline 54 & 22-24 Jun & 35 & $1.85^{\mathrm{b}, \mathrm{c}}$ & 0.18 & 1.13 & 68.1 & 0.48 & 1.1 \\
\hline
\end{tabular}
ments. Values for $\mathrm{DMSP}_{\mathrm{p}}$ and $\mathrm{DMSO}_{\mathrm{p}}$ derived from data sets of Bouillon (1999) and Bouillon et al (2002). L: large; S: small 
of treatment replicates (Table 1). Chl a samples were extracted overnight at $-20^{\circ} \mathrm{C}$ in $90 \%$ acetone, and concentrations were determined by fluorometry (Turner Designs Model 10; Parsons et al. 1984).

Calculation of chlorophyll a ingestion rate. Using data for daily chl a changes per bottle $\left(t_{\mathrm{f}}-t_{0}\right)$, clearance rates were calculated for the copepod assemblage in each replicate bottle according to Frost (1972). Clearance rate was normalized by the biomass of copepods to calculate the specific phytoplankton ingestion rate. Average phytoplankton ingestion rate was calculated for each experiment if 2 or 3 replicate treatment bottles showed net removal of $\operatorname{chl} a_{\text {; }}$ otherwise the chlorophyll ingestion rate was reported as zero (see Table 3: Stn 54, May, 75 m; Stn 49, June, 20 m). A single replicate was deleted from the calculation of specific phytoplankton ingestion rate for an experiment where the remaining 2 replicates showed net removal (Stn 31, June, $15 \mathrm{~m}$ ).

Statistical analyses. Statistical comparison of DMS, $\mathrm{DMSP}_{\mathrm{d}}$, and $\mathrm{DMSO}_{\mathrm{d}}$ concentrations in treatment and control samples (ANOVA followed by StudentNewman-Keuls method for pair-wise multiple comparisons) was computed using the SigmaStat statistical software package (Jandel Scientific Software). Data were checked for their Gaussian distribution and were transformed logarithmically prior to analysis where necessary. Regression analysis was done using SAS statistical software. Multiple regression and multiple analysis of variance (MANOVA) tested the sig- nificance of relationships between weight-specific production rates (for DMS, $\mathrm{DMSP}_{\mathrm{d}}$, and $\mathrm{DMSO}_{\mathrm{d}}$ ) and the following predictor variables: initial chl a concentration, dry weight-specific chl a ingestion rate $\left(\mathrm{h}^{-1}\right)$, average copepod biomass in treatment bottles (mg DW $\mathrm{l}^{-1}$ ), average carapace length of copepods in treatment bottles (mm), depth where water for the incubations was collected (m), month, and numerically dominant copepod group in the treatment bottles.

\section{RESULTS}

\section{Incubation experiments}

The production rates for the dimethylated-sulfur compounds were calculated by subtracting the average change in concentration in the control bottles from the average change in concentration in the treatment bottles. Weight-specific chl a ingestion rate and production rates of $\mathrm{DMS}, \mathrm{DMSP}_{\mathrm{d}}$ and $\mathrm{DMSO}_{\mathrm{d}}$ for all incubation experiments are presented in Table 3. Weight-specific production rates ranged from 0.011 to $2.0 \mathrm{nmol} \mathrm{mg}{ }^{-1} \mathrm{DW} \mathrm{d}{ }^{-1}$ (median $=0.24 \mathrm{nmol} \mathrm{mg}^{-1}$ $\mathrm{DW} \mathrm{d}^{-1}$ ) for DMS, from 0.005 to $6.86 \mathrm{nmol} \mathrm{mg}^{-1} \mathrm{DW} \mathrm{d}^{-1}$ $\left(\right.$ median $\left.=0.71 \mathrm{nmol} \mathrm{mg}^{-1} \mathrm{DW} \mathrm{d}^{-1}\right)$ for $\mathrm{DMSP}_{\mathrm{d}}$, and from 0.014 to $23.0 \mathrm{nmol} \mathrm{mg}^{-1} \mathrm{DW} \mathrm{d}^{-1}$ (median = $1.64 \mathrm{nmol} \mathrm{mg}^{-1} \mathrm{DW} \mathrm{d}^{-1}$ ) for $\mathrm{DMSO}_{\mathrm{d}}$.

Individual and volumetric production rates are often reported in the literature and are summarized here to

Table 3. Chlorophyll a (chl a) ingestion rates and weight-specific production rates for DMS, $\mathrm{DMSP}_{\mathrm{d}}$ and $\mathrm{DMSO}_{\mathrm{d}}$ for each incubation experiment. DW: dry wt; L: large; S: small

\begin{tabular}{|c|c|c|c|c|c|c|c|}
\hline \multirow[t]{2}{*}{ Stn no. } & \multirow[t]{2}{*}{ Date } & \multirow{2}{*}{$\begin{array}{l}\text { Sampling } \\
\text { depth } \\
(\mathrm{m})\end{array}$} & \multirow{2}{*}{$\begin{array}{l}\text { No. of } \\
\text { treatments }\end{array}$} & \multirow{2}{*}{$\begin{array}{l}\text { Ingestion rate } \\
\text { chl } a \\
\left(\mu g \mathrm{mg}^{-1} \mathrm{DW} \mathrm{d}^{-1}\right)\end{array}$} & \multirow{2}{*}{\multicolumn{3}{|c|}{$\begin{array}{ccc} & \text { Production rates } & \\
& \mathrm{DMSP}_{\mathrm{d}} & \mathrm{DMSO}_{\mathrm{d}} \\
\left(\mathrm{nmol} \mathrm{mg}^{-1} \mathrm{DW} \mathrm{d}^{-1}\right) & \left(\mathrm{nmol} \mathrm{mg}^{-1} \mathrm{DW} \mathrm{d}^{-1}\right) & \left(\mathrm{nmol} \mathrm{mg}^{-1} \mathrm{DW} \mathrm{d}^{-1}\right)\end{array}$}} \\
\hline & & & & & & & \\
\hline 44 & 21-23 Apr & $\begin{array}{l}50(\mathrm{l}) \\
50(\mathrm{~s})\end{array}$ & $\begin{array}{l}2 \\
3\end{array}$ & $\begin{array}{l}0.002 \\
0.004\end{array}$ & $\begin{array}{l}0.012 \pm 0.002^{* *} \\
0.014 \pm 0.002^{* *}\end{array}$ & $\begin{array}{l}0.005 \pm 0.018 \\
0.022 \pm 0.029^{* *}\end{array}$ & $\begin{array}{l}0.014 \pm 0.005^{* *} \\
0.041 \pm 0.066\end{array}$ \\
\hline 27 & 27-28 Apr & $\begin{array}{r}35 \\
110\end{array}$ & $\begin{array}{l}3 \\
3\end{array}$ & $\begin{array}{l}0.016^{*} \\
0.0003\end{array}$ & $\begin{array}{c}0.02 \pm 0.01^{* *} \\
0.011 \pm 0.006^{* *}\end{array}$ & $\begin{array}{l}0.046 \pm 0.043^{* *, * * *} \\
0.094 \pm 0.042^{* *}\end{array}$ & $\begin{array}{r}0.097 \pm 0.47 \\
0.22 \pm 0.05\end{array}$ \\
\hline 54 & 25-27 May & $\begin{array}{l}15 \\
75\end{array}$ & $\begin{array}{l}3 \\
1\end{array}$ & $\begin{array}{l}0.49^{*} \\
0\end{array}$ & $\begin{array}{l}0.35 \pm 0.05^{* *, * * *} \\
0.23 \pm 0.13^{* *}\end{array}$ & $\begin{array}{l}0.42 \pm 0.06^{* *, * * *} \\
0.85 \pm 0.05^{* *}\end{array}$ & $\begin{array}{l}0.99 \pm 0.14^{* *} \\
1.64 \pm 0.93\end{array}$ \\
\hline 54 & 05-06 Jun & 11 & 3 & 0.21 & $0.13 \pm 0.04$ & $0.14 \pm 0.34^{* *}$ & $0.16 \pm 0.63$ \\
\hline 49 & 05-06 Jun & 20 & 0 & 0 & $0.57 \pm 0.33^{* *}$ & $0.49 \pm 0.53$ & $0.70 \pm 0.88^{* *}$ \\
\hline 2 & 07-09 Jun & $\begin{array}{l}37(1) \\
37(\mathrm{~s})\end{array}$ & $\begin{array}{l}3 \\
3\end{array}$ & $\begin{array}{l}0.026 \\
0.52\end{array}$ & $\begin{array}{c}0.025 \pm 0.013^{* *} \\
1.44 \pm 2.89^{* *}\end{array}$ & $\begin{array}{l}0.04 \pm 0.02^{* *} \\
2.24 \pm 2.29^{* *}\end{array}$ & $\begin{array}{c}0.032 \pm 0.105 \\
3.58 \pm 6.24\end{array}$ \\
\hline 14 & 10-12 Jun & 15 & 3 & $1.4^{*}$ & $1.58 \pm 0.77^{* *}$ & $1.01 \pm 0.94^{* *}$ & $2.28 \pm 1.95$ \\
\hline 22 & 14-16 Jun & 15 & 3 & 2.2 & $0.41 \pm 0.21^{* *}$ & $0.71 \pm 0.39^{* *}$ & $1.02 \pm 1.57$ \\
\hline 31 & 15-17 Jun & $\begin{array}{l}15 \\
75\end{array}$ & $\begin{array}{l}2 \\
3\end{array}$ & $\begin{array}{l}1.9 \\
0.33^{*}\end{array}$ & $\begin{array}{l}2.00 \pm 0.46^{* *, * * *} \\
0.16 \pm 0.10^{* *}\end{array}$ & $\begin{array}{l}6.86 \pm 1.61^{* *, * * *} \\
2.27 \pm 0.65^{* *}\end{array}$ & $\begin{array}{l}23.0 \pm 6.6^{* *, * * *} \\
7.15 \pm 2.11\end{array}$ \\
\hline 40 & 19-20 Jun & $\begin{array}{l}15 \\
80\end{array}$ & $\begin{array}{l}3 \\
3\end{array}$ & $\begin{array}{l}2.3^{*} \\
0.046\end{array}$ & $\begin{array}{l}0.82 \pm 0.17^{* *} \\
0.24 \pm 0.14^{* *}\end{array}$ & $\begin{aligned} 5.8 & \pm 1.4^{* * * * * * *} \\
2.06 & \pm 0.77^{* *}\end{aligned}$ & $\begin{aligned} 13.2 & \pm 4.2^{* *, * * *} \\
5.2 & \pm 2.1\end{aligned}$ \\
\hline 54 & 22-24 Jun & 35 & 3 & $0.18^{*}$ & $0.16 \pm 0.10^{* *}$ & $1.00 \pm 0.37^{* *}$ & $1.7 \pm 0.7^{* *}$ \\
\hline
\end{tabular}


facilitate comparison with other studies. Individual production rates ranged from 0.004 to $1.42 \mathrm{nmol} \mathrm{ind.}^{-1}$ $\mathrm{d}^{-1}$ (median: $0.2 \mathrm{nmol}$ ind..$^{-1} \mathrm{~d}^{-1}$ ) for DMS, from 0.003 to $1.57 \mathrm{nmol}$ ind..$^{-1} \mathrm{~d}^{-1}$ (median $=0.15 \mathrm{nmol}$ ind.$^{-1} \mathrm{~d}^{-1}$ ) for $\mathrm{DMSP}_{\mathrm{d}}$ and from 0.005 to $2.74 \mathrm{nmol}$ ind. ${ }^{-1} \mathrm{~d}^{-1}$ $\left(\right.$ median $=0.29 \mathrm{nmol}$ ind.$\left.^{-1} \mathrm{~d}^{-1}\right)$ for $\mathrm{DMSO}_{\mathrm{d}}$. Volumetric production rates of DMS resulting from copepod grazing ranged from 0.082 to $3.82 \mathrm{nmol} \mathrm{l^{-1 }} \mathrm{d}^{-1}$ (median = $\left.0.64 \mathrm{nmol} \mathrm{\textrm {l } ^ { - 1 }} \mathrm{d}^{-1}\right)$, corresponding to a 15 to $350 \%$ increase in concentration over controls (median = $43 \%$ ). For DMSP $\mathrm{D}_{\mathrm{d}}$, production rates by copepods varied between 0.04 and $8.14 \mathrm{nmol} \mathrm{l}^{-1} \mathrm{~d}^{-1}$ (median: $1.27 \mathrm{nmol} \mathrm{l}^{-1} \mathrm{~d}^{-1}$ ), an increase of 12 to $620 \%$ (median: $56 \%$ ) over the controls. Volumetric production rates

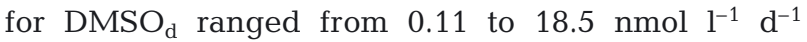
$\left(\right.$ median $\left.=2.66 \mathrm{nmol} \mathrm{l}^{-1} \mathrm{~d}^{-1}\right)$, which represented an increase in concentration of 11 to $120 \%$ (median = $17 \%$ ) over control samples.

\section{Factors contributing to variations in production rates}

DMS, $\mathrm{DMSP}_{\mathrm{d}}$ and $\mathrm{DMSO}_{\mathrm{d}}$ production rates showed no relationship to initial chlorophyll concentration in the incubations ( $p>0.15$ in each case). However, slightly less than half of the variation in dimethylatedsulfur production rates was explained by chl a ingestion rate (Fig. 2). The strongest of these relationships was between the production of $\mathrm{DMSP}_{\mathrm{d}}$ and chl a ingestion rates $\left(\mathrm{r}^{2}=0.47, \mathrm{p}=0.0025, \mathrm{n}=17\right)$. There was also a negative relationship between the weight-specific production rate for each dimethylated-sulfur compound and the dry weight of the experimental copepod assemblage $\left(\mathrm{r}^{2}=0.41, \mathrm{p}=0.0055\right)$. This relationship may have been due to a decrease in the biomass of copepods in the treatment containers that resulted from a decrease in the average carapace length of the copepods. Copepod size decreased markedly when early-stage Calanus spp. became numerically dominant in June (Table 1). The negative relationship is unlikely to have resulted from decreases in the DMSP and DMSO contents of the phytoplankton cells, as available evidence $\left(\mathrm{DMSP}_{\mathrm{p}}\right.$ :chl $a$ and $\mathrm{DMSO}_{\mathrm{p}}: \mathrm{chl} a$ ratios) suggests that the DMSP and DMSO contents were also decreasing during the sampling period (Bouillon et al. 2002)

The MANOVA model simplified to 4 significant explanatory variables for the 3 production-rate variables (DMS, DMSP $d, \mathrm{DMSO}_{\mathrm{d}}$ ): (1) chl a ingestion rate $\left(\mathrm{h}^{-1}\right)_{i}(2)$ dry weight of copepods in treatments $\left(\mathrm{mg} \mathrm{l}^{-1}\right)$; (3) phytoplankton collection depth $(\mathrm{m})$; (4) ingestion rate $\times$ depth (interaction term). Partial correlation $\mathrm{co}-$ efficients showed that $\mathrm{DMSP}_{\mathrm{d}}$ and $\mathrm{DMSO}_{\mathrm{d}}$ production rates $(\mathrm{PR})$ had similar relationships to the explanatory variables of this model $(r=0.84, \operatorname{Pr}>|r|=0.0095, \mathrm{n}=8)$.

\section{Dimethylated-sulfur productivity ratios}

The productivity rates of the dimethylated-sulfur compounds were coupled to each other, as illustrated by Fig. 3. The rate of $\mathrm{DMSO}_{\mathrm{d}}$ production was strongly related to that of $\mathrm{DMSP}_{\mathrm{d}}\left(\mathrm{r}^{2}=0.95, \mathrm{p} \leq 0.05, \mathrm{n}=17\right)$. The rate of DMS production was also related to the rate of DMSP $_{d}$ production $\left(\mathrm{r}^{2}=0.51, \mathrm{p} \leq 0.05, \mathrm{n}=17\right)$. The overall ratios of these fluxes were 2.9 for

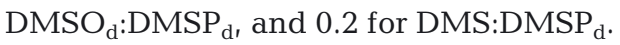
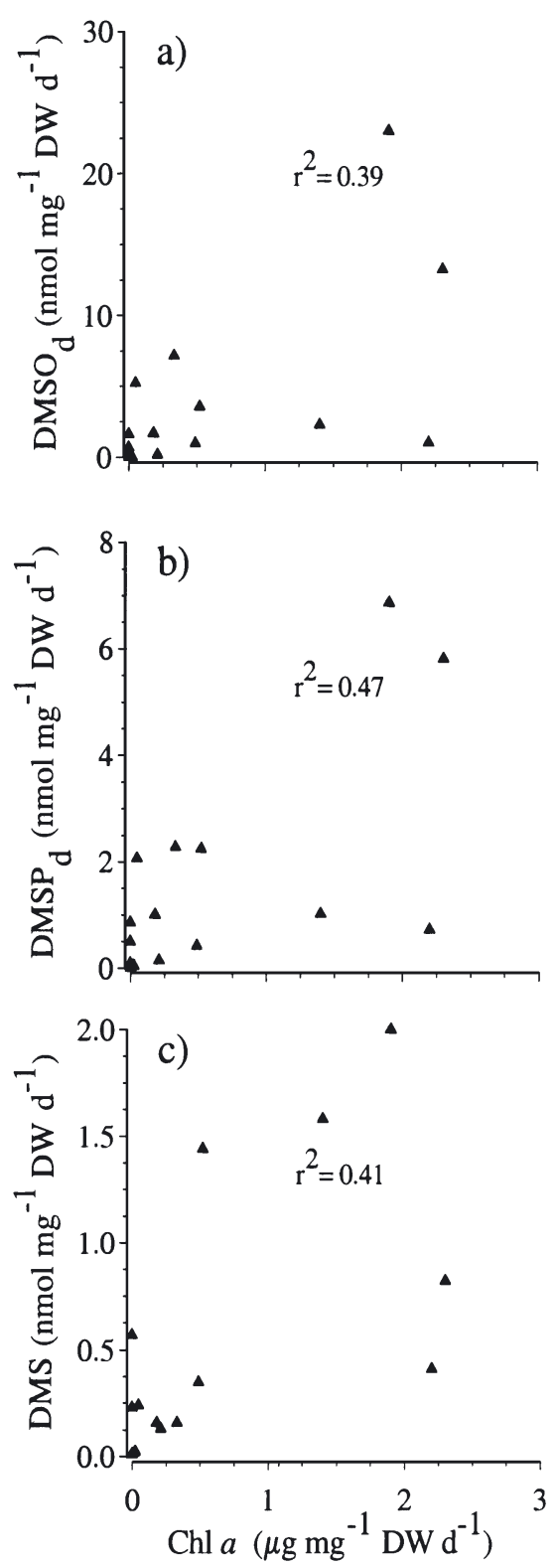

Fig. 2. Scatter plots between weight-specific chlorophyll a (chl a) ingestion rates and (a) weight-specific $\mathrm{DMSO}_{\mathrm{d}}$ production rates, (b) weight-specific $\mathrm{DMSP}_{\mathrm{d}}$ production rates, and (c) weight-specific DMS production rate 


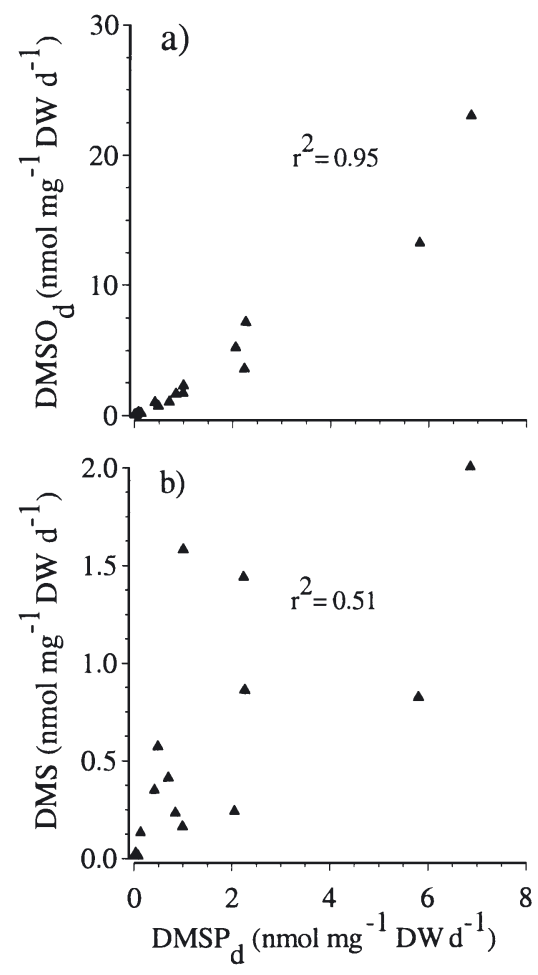

Fig. 3. Scatter plots between weight-specific production rates for (a) $\mathrm{DMSP}_{\mathrm{d}}$ and $\mathrm{DMSO}_{\mathrm{d}}$, and (b) $\mathrm{DMSP}_{\mathrm{d}}$ and DMS

\section{DISCUSSION}

This study is the first to demonstrate that mesozooplankton grazing can influence dissolved DMSO concentrations. However, the difference between treatments and controls was not always statistically significant. Furthermore, differences were observed between the statistical significance of the increase in concentrations of DMS and DMSP $\mathrm{d}_{\mathrm{d}}$ and those of $\mathrm{DMSO}_{\mathrm{d}}$. The production rate of $\mathrm{DMSO}_{\mathrm{d}}$ in the treatments was significantly greater than in the controls in only $35 \%$ of the experiments. Conversely, production rates for $\mathrm{DMSP}_{\mathrm{d}}$ and DMS in treatments were significantly greater than rates in controls in 94 and $88 \%$, respectively, of the experiments. These results suggest that copepod grazing is relatively less important in the biogeochemical cycling of $\mathrm{DMSO}_{\mathrm{d}}$ than it is for DMS and $\mathrm{DMSP}_{\mathrm{d}}$. Whether this is a genuine finding or an artifact of the incubation experiments is difficult to assess. Slightly higher analytical errors associated with the determination of DMSO (see 'Materials and methods') are likely to contribute to increased uncertainties in the rate measurements for $\mathrm{DMSO}_{\mathrm{d}}$ production that may translate into treatments and controls being statistically similar. To overcome this, the use of a larger number of replicates for both treatments and controls will be required for future experiments. Some potential biogeochemical explanations for this finding are discussed in various sections of the following text.

Since studies have shown that DMSO is present in phytoplankton (Simó et al. 1998, Lee et al. 1999), it has been argued that zooplankton might release intracellular DMSO during grazing, thereby influencing dissolved DMSO concentrations (Lee \& de Mora 1999). While the results presented here do not provide direct evidence of the release of intracellular DMSO, they do support this hypothesis. In the North Water, a significant linear correlation ( $\leq \leq 0.05$, Fig. 2 ) was observed between production rates for $\mathrm{DMSP}_{\mathrm{d}}$ and $\mathrm{DMSO}_{\mathrm{d}}$. Similarly, a poorer but still significant correlation was found between DMS and DMSP ${ }_{\mathrm{d}}$. Conventionally, it is accepted that DMS is produced as a result of enzymatic cleavage of $\mathrm{DMSP}_{\mathrm{d}}$ released into the water column during sloppy feeding and/or transformation of $\mathrm{DMSP}_{\mathrm{p}}$ ingested by zooplankton. If $\mathrm{DMSO}_{\mathrm{d}}$ were formed from the oxidation of DMS, it is hard to accept that the correlation between $\mathrm{DMSP}_{\mathrm{d}}$ and $\mathrm{DMSO}_{\mathrm{d}}$ would be better than the correlation between DMS and $\mathrm{DMSP}_{d}$ (Fig. 3). Since a very strong correlation exists between the production of $\mathrm{DMSP}_{\mathrm{d}}$ and $\mathrm{DMSO}_{\mathrm{d}}$, this indicates that the $\mathrm{DMSO}_{\mathrm{d}}$ most likely originates from within phytoplankton cells. Further evidence for the direct release of $\mathrm{DMSO}_{\mathrm{p}}$ during grazing comes from the MANOVA model derived for this study. If $\mathrm{DMSO}_{d}$ were a degradation by-product of the grazing process, as is DMS, then the expectation would be that the factors affecting the variability of these 2 compounds would be similar. However, the partial correlation coefficients associated with the model did not indicate this. Alternatively, if $\mathrm{DMSO}_{\mathrm{p}}$ were being directly released due to grazing, as is $\mathrm{DMSP}_{\mathrm{p}}$, then the factors affecting the variability of $\mathrm{DMSP}_{\mathrm{d}}$ and $\mathrm{DMSO}_{\mathrm{d}}$ should be similar. The model showed that $\mathrm{DMSP}_{\mathrm{d}}$ and $\mathrm{DMSO}_{\mathrm{d}}$ production rates had similar relationships to the explanatory variables, which suggests that DMSP and DMSO share a similar intracellular source.

\section{Experimental results}

The individual-normalized rates for the production of DMS and DMSP ${ }_{d}$ by copepods presented here are at the lower end of the range of values previously measured by other investigators (Table 4). Ancillary information such as phytoplankton communities, predator types and predator concentrations used by the other investigators and in this study is also provided in Table 4. Since no other study has been reported that examined whether $\mathrm{DMSO}_{\mathrm{d}}$ levels are affected by zooplankton grazing, no comparisons with other studies are possible. 


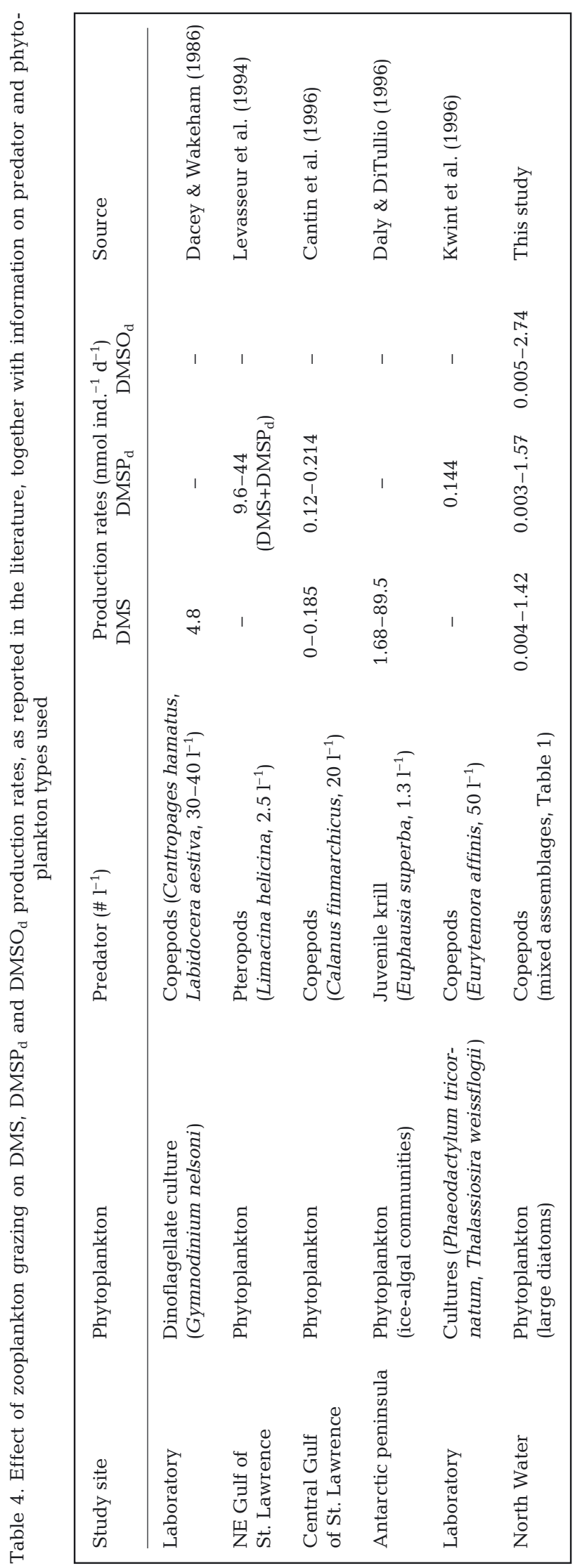

Several factors are likely to be responsible for the observed differences in production rates observed between this and other studies. The relatively low DMS and $\mathrm{DMSP}_{\mathrm{d}}$ production rates may have arisen from differences in predator size or activity compared to other studies. While the use of volume-based and individual-normalized production rates allows comparison of the results from this study with previously published results, differences in the type of grazers used (i.e. small copepods vs large copepods vs different species/life stages of krill) should be considered. Additionally, the rates at which phytoplankton are consumed, if they are consumed, will also have contributed to the observed variations. The effects of phytoplankton consumption rates on the production of the dimethylated-sulfur species are discussed below. Production rates normalized to copepod biomass will be used in preference to the other rates throughout this discussion, since they allow the most ecologicallyuseful comparison of the experiments conducted under different conditions in the North Water.

The low weight-specific production rates observed during this study are probably due in part to the low DMSP content of the phytoplankton community. Average DMSP $_{\mathrm{p}}$ :chl a ratios in the upper $25 \mathrm{~m}$ of the water-

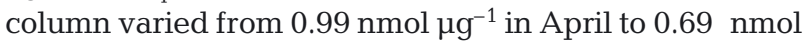
${\mu \mathrm{g}^{-1}}^{-1}$ in May to $0.47 \mathrm{nmol} \mathrm{\mu g}^{-1}$ in June (Bouillon et al. 2002). It should be noted that there was a considerable increase in average in situ chl a levels in the upper $25 \mathrm{~m}$ of the water column during the same period (from $0.61 \mu \mathrm{g} \mathrm{l}^{-1}$ in April to $4.85 \mu \mathrm{g} \mathrm{l}^{-1}$ in May to $7.21 \mu \mathrm{g} \mathrm{l}^{-1}$ in June, Bouillon et al. 2002). The taxonomic composition of the phytoplankton community was dominated by relatively large (20 to $200 \mu \mathrm{m}$ ) diatoms, particularly during early June when the majority of these experiments was completed (Booth et al. 2002, Lovejoy et al. 2002). In April, the phytoplankton biomass was dominated by Actinocyclus spp./Coscinodiscus spp. These were followed by Thalassiosira spp./Porosira glacialis in May and early June, and finally by Chaetoceros spp. in late June and July. In general, diatoms are not considered to be important producers of DMSP (Keller et al. 1989).

\section{Factors contributing to variations in $\mathrm{DMS}_{,} \mathrm{DMSP}_{\mathrm{d}}$ and $\mathrm{DMSO}_{\mathrm{d}}$ production rates}

Several factors could influence the relative magnitude of the production rates determined in these incubations. Partial correlation analysis also showed that much of the variability in dimethylated-sulfur production rates was related to chl a ingestion rates, and the close relationship of variance in copepod-induced $\mathrm{DMSP}_{\mathrm{d}}$ and $\mathrm{DMSO}_{\mathrm{d}}$ production rates. This indicates 


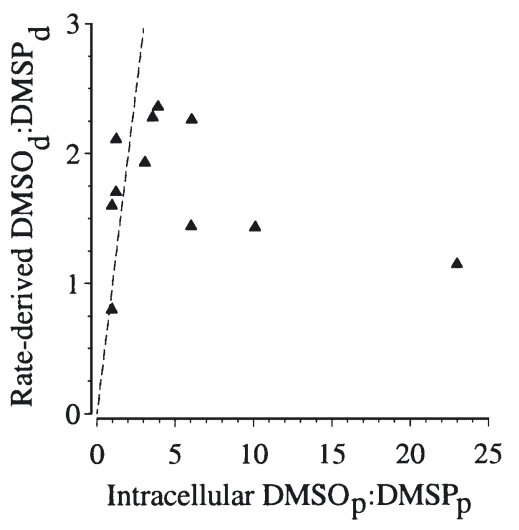

Fig. 4. Scatter plot between $\mathrm{DMSO}_{\mathrm{d}}: \mathrm{DMSP}_{\mathrm{d}}$ and $\mathrm{DMSO}_{\mathrm{p}}$ : $\mathrm{DMSP}_{\mathrm{p}}$. Values for $\mathrm{DMSO}_{\mathrm{d}}: \mathrm{DMSP}_{\mathrm{d}}$ were calculated from weight-specific production rates for the dimethylated-sulfur compounds in question. Values for $\mathrm{DMSO}_{\mathrm{p}}: \mathrm{DMSP}_{\mathrm{p}}$ were taken from data sets of Bouillon (1999) and Bouillon et al. (2002). Dashed line depicts 1:1 relationship between $x$ and $y$ parameter

that the rates at which the dimethylated-sulfur compounds were produced were related to the rates at which copepods consumed phytoplankton. The significant interaction term (ingestion rate $\times$ depth) indicated that higher rates of dimethylated sulfur production occurred in those experiments having phytoplankton collected from shallower depths. The 4 experiments with the highest $\mathrm{chl}$ a ingestion rates were conducted at adjacent stations within a $9 \mathrm{~d}$ period of time suggesting that these stations may have represented a 'peak' bloom phase for diatoms such as Thalassiosira sp., and that the condition and location of the phytoplankton bloom was optimal for copepod grazing (Booth et al. 2002). Another possibility is that the copepod assemblages (early-stage Calanus spp.) in these experiments were eating at higher rates than assemblages dominated by larger copepods. However, 3 other experiments with copepod treatments dominated by early-stage Calanus spp. did not show such high specific chl a ingestion rates (Tables $2 \& 3$ ). Furthermore, at least 2 of these stations did not have high concentrations of large diatoms (P.A.S. et al. unpubl. results). Despite the potential importance of copepod assemblage characteristics, the significance of phytoplankton-collection depth in the model adds support to the idea that the characteristics of the phytoplankton community are significant to chl a ingestion rates and dimethylated-sulfur production rates.

The partial correlation coefficients showed that the pattern for the variability of the weight-specific production rates for DMS was different from that of $\mathrm{DMSP}_{\mathrm{d}}$ and $\mathrm{DMSO}_{\mathrm{d}}$. This is not unexpected, given that DMS is a degradation product in the grazing process and not released directly during feeding. Thus, varia- tions in the production rates of DMS were influenced by variations in the processes that cause its formation, as well as by variations in the factors that influence the release of its precursor, $\mathrm{DMSP}_{\mathrm{d}}$.

\section{DMS, $_{\text {DMSP }}$ and $\mathrm{DMSO}_{\mathrm{d}}$ productivity ratios}

The different productivity ratios of the various dimethylated-sulfur compounds suggest that the compounds are not affected in equal proportions by copepod grazing. If it is assumed that the grazing process affects DMSP and DMSO equally, then the ratio of the rates at which they are released into the dissolved phase should be equivalent to the ratio of DMSP to DMSO within the phytoplankton. The average in situ $\mathrm{DMSO}_{\mathrm{p}}: \mathrm{DMSP}_{\mathrm{p}}$ ratio for the stations and depths where the phytoplankton samples were collected for the incubation experiments was 5.5 (Bouillon 1999, Bouillon et al. 2002). The slope of the relationship between the weight-specific production rates for $\mathrm{DMSP}_{\mathrm{d}}$ and $\mathrm{DMSO}_{\mathrm{d}}$ was 2.9 (Fig. 3). Direct comparison of the $\mathrm{DMSO}_{\mathrm{d}}$ : $\mathrm{DMSP}_{\mathrm{d}}$ ratios with the equivalent ratios for the particulate-phase material shows that intracellular ratios are generally higher than the release rate ratios (Fig. 4). The difference between the release rate ratios and the particulate ratio indicates that there is either removal of DMSO relative to DMSP, or input of DMSP relative to DMSO. However, it is difficult to determine which of these 2 possibilities may have occurred.

Differences in the distribution of $\mathrm{DMSP}_{\mathrm{p}}$ and $\mathrm{DMSO}_{\mathrm{p}}$ within phytoplankton cells might cause variations in the rate of release of these compounds, particularly in the case of sloppy feeding. If $\mathrm{DMSP}_{\mathrm{p}}$ and $\mathrm{DMSO}_{\mathrm{p}}$ are not distributed uniformly throughout the phytoplankton cell, then there may be 'enhanced' release of 1 of these compounds if the prey is only partially eaten. The ratio of intracellular DMSO:DMSP may vary from one species of phytoplankton to another, leading to variations in release rates during grazing, particularly if grazers avoid phytoplankton with a DMSP/DMSPlyase defence mechanism (Wolfe \& Steinke 1996, Wolfe et al. 1997). However, given the taxonomic composition and low DMSP content of the phytoplankton community in the North Water (Bouillon et al. 2002), species possessing such a defense mechanism are unlikely to be important.

It has been shown that copepods can decrease their body content of DMSP in response to decreases in external salinity (Tang et al. 1999), thereby providing a mechanism for the input of extra DMSP into the dissolved phase. While salinity changes during the course of the incubations are very unlikely, the copepods may have experienced varying salinity conditions between their capture and addition to the incubation bottles. 
This may have caused the copepods to adjust their intracellular DMSP levels. Tang et al. (2001) showed recently that the body of the copepod Acartia tonsa and its fecal pellets contain dense populations of DMSP-consuming bacteria relative to the surrounding seawater and that the bacteria are capable of consuming a significant quantity of DMSP that passes through the copepods. Furthermore, the turnover of bodyDMSP is dependent on the copepod species involved. In the case of Acartia tonsa turnover is rapid (Tang et al. 2000), whereas body-DMSP is stable in Temora longicornis (Tang et al. 1999, 2000). While it is difficult to assess how these factors could have influenced $\mathrm{DMS}_{1} \mathrm{DMSP}_{\mathrm{d}}$ and $\mathrm{DMSO}_{\mathrm{d}}$ production rates in the present experiments, they could have introduced some variability into the relative rates.

It is known that not all the $\operatorname{DMSP}_{\mathrm{p}}$ present in the phytoplankton will reach the dissolved phase, as some DMSP $_{\mathrm{p}}$ may be packaged into fecal pellets (Daly \& DiTullio 1996, Kwint et al. 1996) and some DMSP $_{p}$ may be used by zooplankton for osmoregulation (Tang et al. 1999). An alternative possibility, albeit speculative, is that $\mathrm{DMSO}_{\mathrm{p}}$ is being lost due to uptake by the copepods for metabolic use. Currently, it is not known whether DMSO is a metabolite for marine organisms, but evidence from terrestrial environments indicates that metabolic pathways for DMSO are present in terrestrial organisms (Lee \& de Mora 1999; and references therein). Finally, the possibility that some of the variability in both the production rates and productivity ratios may result from a cascade of effects caused by the addition of the copepods to the treatment bottles cannot be ignored. Since grazing by the copepods causes the direct release of DMS, DMSP and DMSO, bacteria and microzooplankton present in treatment bottles will probably transform these compounds during relatively long incubations, such as those in the present study.

Comparison of $\mathrm{DMSP}_{\mathrm{d}}: \mathrm{chl} a$ or $\mathrm{DMSO}_{\mathrm{d}}: \mathrm{chl}$ a ratios derived from the weight-specific production and ingestion rates with the equivalent ratios for the particulate-phase material (Fig. 5) shows that more DMS, DMSP, and DMSO was being released into the dissolved phase than was potentially available in the phytoplankton. This finding suggests that copepods were consuming phytoplankton with dimethylatedsulfur:chl a ratios higher than the average ratio measured for the particulate-phase material. This could be due to selective feeding by the copepods on prey with higher concentrations of dimethylated-sulfur. Some copepods may have also consumed other predators that had accumulated dimethylated-sulfur and therefore contained higher intracellular concentrations of dimethylated-sulfur (as per the finding of Levasseur et al. 1994). While these comparisons suggest that there
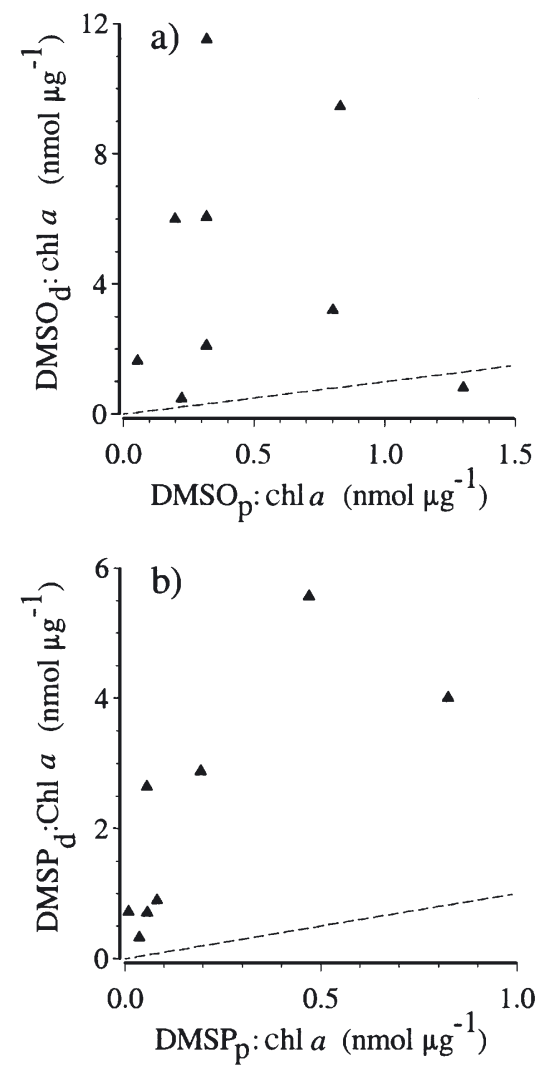

Fig. 5. Scatter plots between (a) $\mathrm{DMSO}_{\mathrm{d}}$ :chlorophyll $a$ and DMSO $_{\mathrm{p}}$ :chlorophyll $a$, and (b) DMSP $\mathrm{d}$ :chlorophyll $a$ and DMSP chlorophyll $a$. Values for $\mathrm{DMSO}_{\mathrm{d}}$ :chlorophyll $a$ and $\mathrm{DMSP}_{\mathrm{d}}$ : chlorophyll a were calculated by dividing weight-specific production rates for the dimethylated-sulfur compound in question by the weight-specific chl a ingestion rate. Values for $\mathrm{DMSO}_{\mathrm{p}}$ :chlorophyll $a$ and $\mathrm{DMSP}_{\mathrm{p}}$ :chlorophyll a were taken from data sets of Bouillon (1999) and Bouillon et al. (2002). Dashed line depicts 1:1 relationship between the $x$ and $y$ parameters

may have been input of non-phytoplankton dimethylated-sulfur, they do not show if that input preferentially favored DMSP.

\section{In situ production rates}

Extrapolation of the results obtained during the incubation experiments to the in situ conditions in the water column of the polynya are presented in Table 5. Some of the initial experiments appear to correspond to average water-column concentrations of dimethylated-sulfur that are lower than the detection limit for these compounds. At these stations, in situ concentrations are zero at some depths yielding the apparently low values averaged for the water column.

The observations made during the incubations showed that mesozooplankton grazing is highly signif- 
Table 5. Average water-column concentrations of DMS, $\mathrm{DMSP}_{\mathrm{d}}$ and $\mathrm{DMSO}_{\mathrm{d}}$ determined at each station together with in situ copepod biomass and calculated in situ production rates for $\mathrm{DMS}, \mathrm{DMSP}_{\mathrm{d}}$ and $\mathrm{DMSO}_{\mathrm{d}}$ for each station/experiment. Average water-column concentrations for dimethylated-sulfur compounds were derived from data sets of Bouillon (1999) and Bouillon et al. (2002). L: large; S: small

\begin{tabular}{|c|c|c|c|c|c|c|c|c|}
\hline \multirow[t]{2}{*}{ Stn no. } & \multirow{2}{*}{$\begin{array}{c}\text { Sampling } \\
\text { depth } \\
\text { (m) }\end{array}$} & \multicolumn{3}{|c|}{$\begin{array}{l}\text { Avg. water-column } \\
\text { concentration }\end{array}$} & \multirow{2}{*}{$\begin{array}{c}\text { In situ } \\
\text { copepod } \\
\text { biomass } \\
\left(\mathrm{mg} \mathrm{DW} \mathrm{m}^{-3}\right)\end{array}$} & \multicolumn{3}{|c|}{ In situ production rate } \\
\hline & & $\begin{array}{c}\text { DMS } \\
\left(\mathrm{nmol} \mathrm{m}^{-3}\right)\end{array}$ & $\underset{\left(\mathrm{nmol} \mathrm{m}^{-3}\right)}{\mathrm{DMSP}_{\mathrm{d}}}$ & $\begin{array}{c}\mathrm{DMSO}_{\mathrm{d}} \\
\left(\mathrm{nmol} \mathrm{m}^{-3}\right)\end{array}$ & & $\begin{array}{c}\text { DMS } \\
\left(\mathrm{nmol} \mathrm{m}^{-3} \mathrm{~d}^{-1}\right)\end{array}$ & $\begin{array}{c}\operatorname{DMSP}_{\mathrm{d}} \\
\left(\mathrm{nmol} \mathrm{m}^{-3} \mathrm{~d}^{-1}\right)\end{array}$ & $\begin{array}{c}\mathrm{DMSO}_{\mathrm{d}} \\
\left(\mathrm{nmol} \mathrm{m}^{-3} \mathrm{~d}^{-1}\right)\end{array}$ \\
\hline \multirow[t]{2}{*}{44} & $50(1)$ & 3.8 & 75.9 & 20200 & 0.194 & 0.002 & 0.001 & 0.003 \\
\hline & $50(\mathrm{~s})$ & 3.8 & 75.9 & 20200 & 0.521 & 0.007 & 0.011 & 0.021 \\
\hline \multirow[t]{2}{*}{27} & 35 & 133 & 334 & 46700 & 2.11 & 0.042 & 0.097 & 0.21 \\
\hline & 110 & 26.2 & 256 & 32300 & 2.47 & 0.027 & 0.23 & 0.54 \\
\hline \multirow[t]{2}{*}{54} & 15 & 1140 & 1280 & 53600 & 49.4 & 17.3 & 20.7 & 48.9 \\
\hline & 75 & 266 & 258 & 34800 & 0.85 & 0.20 & 7.22 & 13.9 \\
\hline 54 & 11 & 582 & 1750 & 41900 & 132 & 17.2 & 18.5 & 21.1 \\
\hline 49 & 20 & 1210 & 3540 & 73000 & 26.1 & 14.9 & 12.8 & 18.3 \\
\hline \multirow[t]{2}{*}{2} & $37(1)$ & 76.3 & 259 & 40500 & 39.5 & 0.99 & 1.50 & 1.26 \\
\hline & $37(\mathrm{~s})$ & 76.3 & 259 & 40500 & 15.1 & 21.7 & 33.9 & 5.41 \\
\hline 14 & 15 & 361 & 2380 & 70400 & 2.23 & 3.52 & 2.25 & 5.07 \\
\hline 22 & 15 & 443 & 1190 & 54300 & 6.34 & 2.60 & 4.50 & 6.47 \\
\hline \multirow[t]{2}{*}{31} & 15 & 512 & 1650 & 61900 & 6.91 & 13.8 & 47.4 & 159 \\
\hline & 75 & 178 & 1780 & 52600 & 6.85 & 5.89 & 15.6 & 49.0 \\
\hline \multirow[t]{2}{*}{40} & 15 & 960 & 3600 & 74700 & no data & - & - & - \\
\hline & 80 & 289 & 1800 & 51700 & 35.4 & 8.50 & 72.8 & 184 \\
\hline 54 & 35 & 263 & 2110 & 54700 & 85.8 & 13.7 & 85.8 & 146 \\
\hline
\end{tabular}

icant to the biogeochemical cycling of DMS and $\mathrm{DMSP}_{\mathrm{d}}$. Although the production rates measured for $\mathrm{DMSO}_{\mathrm{d}}$ were generally the largest of the 3 dimethylated-sulfur compounds, a lower frequency of statistically significant copepod effects may indicate that mesozooplankton grazing could be less important in the biogeochemical cycling of $\mathrm{DMSO}_{\mathrm{d}}$. However, these findings do not preclude the possibility that other types of meso- and micro-zooplankton grazers (such as salps and ciliates) may have a different (and potentially more significant) impact on the in situ generation of these 3 compounds (Belviso et al. 1990, Kasamatsu et al. 2002).

Calculation of turnover times based on the average water-column concentrations measured at each station and the in situ production rates suggest that copepod grazing in the North Water is unimportant as a release mechanism for the 3 dimethylated-sulfur compounds. For DMS and $\mathrm{DMSP}_{\mathrm{d}}$, the average time required to generate the observed ambient levels of these 2 compounds through copepod grazing alone ranged from 4 to $3171 \mathrm{~d}$ (median $=79 \mathrm{~d}$ ) and from 8 to $75900 \mathrm{~d}$ $($ median $=144 \mathrm{~d})$, respectively. In the case of $\mathrm{DMSO}_{\mathrm{d}}$, the time required ranged from 281 to $6700000 \mathrm{~d}$ $($ median $=5738 \mathrm{~d})$. If only the data from June are considered, when production rates were highest, the median turnover times become 36, 105 and $2989 \mathrm{~d}$ for $\mathrm{DMS} \mathrm{DMSP}_{\mathrm{d}}$ and $\mathrm{DMSO}_{\mathrm{d}}$, respectively. Lee (1999) calculated much faster turnover times for the loss of DMS due to photolysis, microbial consumption and sea-air transfer in the North Water in June 1998 (0.07 to $1.4,0.04$ to 1.4 and 0.09 to $10 \mathrm{~d}$, respectively). Furthermore, Lee (1999) found that $\mathrm{DMSO}_{d}$ was rapidly lost through photolysis and microbial consumption (24 to 77 and 2 to $26 \mathrm{~d}$, respectively). Thus, the mismatch between the shorter turnover times for the DMS and $\mathrm{DMSO}_{\mathrm{d}}$ loss mechanisms and the longer turnover times for the generation of these compounds due to copepod grazing points to the relative unimportance of copepod grazing on the biogeochemical cycling of dimethylated sulfur compounds in the North Water.

Acknowledgements. We would like to express our deepest gratitude to the people of Qaanaaq, Greenland, for their cooperation during the expedition. We are grateful to the Canadian Coast Guard for the use of the CCGS 'Pierre Radisson', and are appreciative of the marvelous support provided by her officers and crews. We would also like to thank R.C. Bouillon (Dalhousie University) for assistance with the preparation of samples, E.A. Hatfield (Memorial University of Newfoundland) for analysis of the chlorophyll samples, S.H. Lee (Memorial University of Newfoundland) for analysis of the copepod samples, and our scientific colleagues on the 'Pierre Radisson' for their many productive and stimulating discussions. We gratefully acknowledge the helpful comments provided by Dr. Jack DiTullio (College of Charleston, Hollings Marine Laboratory) and several anonymous reviewers on earlier versions of this manuscript. This work is a contribution to 
the International North Water Polynya Project, which has been made possible through funding from the National Science and Engineering Research Council (NSERC) of Canada, and logistical support from the Polar Continental Shelf Project (Energy, Mines and Resources Canada) and the Canadian Coast Guard.

\section{LITERATURE CITED}

Andreae MO (1980) Determination of trace quantities of DMSO in aqueous solution. Anal Chem 52:150-153

Andreae MO (1990) Ocean-atmosphere interactions in the global biogeochemical cycle of sulfur. Mar Chem 30:1-29

Bâcle J, Carmack EC, Ingram RG (2002) Water column structure and circulation under the North Water during spring transition: April-July, 1998. Deep-Sea Res II 49:4907-4125

Belviso S, Kim SK, Rassoulzadegan F, Krajka B, Nguyen BC, Buat-Menard P (1990) Production of dimethylsulfonium propionate (DMSP) and dimethylsulfide (DMS) by a microbial food web. Limnol Oceanogr 35:1810-1821

Booth BC, Larouche P, Belanger S, Klein B, Amiel D, Mei ZP (2002) Dynamics of Chaetoceros socialis blooms in the North Water. Deep-Sea Res II 49:5003-5025

Bouillon RC (1999) Concentrations et variations spatiotemporelles du DMS, DMSP et DMSO dans la région des Eaux du Nord, Mer de Baffin. MSc thesis, Université du Québec à Rimouski, Rimouski

Bouillon RC, Lee PA, de Mora SJ, Levasseur M, Lovejoy C (2002) Vernal distribution of dimethylsulphide, dimethylsulphoniopropionate and dimethylsulphoxide in the North Water in 1998. Deep-Sea Res II 49:5171-5189

Bratbak G, Levasseur M, Michaud S, Cantin G, Fernandez E, Heimdal B, Heldal M (1995) Virus activity in relation to Emiliania huxleyi blooms: a mechanism of DMSP release? Mar Ecol Prog Ser 128:133-142

Brimblecombe P, Shooter D (1986) Photo-oxidation of dimethylsulphide in aqueous solution. Mar Chem 19:343-353

Cantin G, Levasseur M, Gosselin M, Michaud S (1996) Role of zooplankton in the mesoscale distribution of surface dimethylsulfide concentrations in the Gulf of St. Lawrence, Canada. Mar Ecol Prog Ser 141:103-117

Charlson RE, Lovelock JE, Andreae MO, Warren SG (1987) Oceanic phytoplankton, atmospheric sulfur, cloud albedo and climate. Nature 326:655-661

Christaki U, Belviso S, Dolan JR, Corn M (1996) Assessment of the role of copepods and ciliates in the release to solution of particulate DMSP. Mar Ecol Prog Ser 141:119-127

Dacey JWH, Wakeham S (1986) Oceanic dimethylsulfide production during zooplankton grazing on phytoplankton. Science 233:1314-1316

Daly KL, DiTullio GR (1996) Particulate dimethylsulfoniopropionate removal and dimethylsulfide production by zooplankton in the Southern Ocean. In: Kiene RP, Visscher PT, Keller MD, Kirst GO (eds) Biological and environmental chemistry of DMSP and related sulfonium compounds, Plenum Press, New York, p 223-238

Darby MS, Willmott AJ, Mysak LA (1994) A nonlinear steadystate model of the North Water polynya, Baffin Bay. J Phys Oceanogr 24:1011-1020

Deming JW, Fortier L, Fukuchi M (2002) The International North Water Polynya Project (NOW): an overview. DeepSea Res II 49:4887-4892

de Mora SJ, Lee P, Grout A, Schall C, Heumann K (1996) Aspects of the biogeochemistry of sulfur in glacial melt water ponds on the McMurdo Ice Shelf, Antarctica. Antarct Sci 8:15-22
Dickson DMJ, Kirst GO (1986) The role of $\beta$-dimethylsulphoniopropionate, glycine betaine and homarine in the osmoacclimation of Platymonas subcordiformis. Planta 167:536-543

Frost BW (1972) Effects of size and concentration of food particles on the feeding behavior of the marine planktonic copepod Calanus pacificus. Limnol Oceanogr 17:805-815

Hill RW, White BA, Cottrell MT, Dacey JWH (1998) Virusmediated total release of dimethylsulfoniopropionate from marine phytoplankton: a potential climate process. Aquat Microb Ecol 14:1-6

Ingram RG, Bâcle J, Barber DG, Gratton Y, Melling H (2002) Physical processes in the North Water. Deep-Sea Res Part II Top Stud Ecol 49:4893-4906

Kasamatsu N, Kawaguchi S, Watanabe S, Odate T, Fukuchi M (2002) Possible impacts of zooplankton grazing on DMS production in the Antarctic Ocean. In: Third International Symposium on Biological and Environmental Chemistry of DMS(P) and Related Compounds, Rimouski (Québec), Canada. Available at http://www.qc.dfo-mpo.gc.ca/iml/en/ DMSP/completeProgramme.pdf

Keller MD, Bellows WK, Guillard RRL (1989) Dimethyl sulfide production in marine phytoplankton. In: Saltzman ES, Cooper WJ (eds) Biogenic sulfur in the environment. American Chemical Society, Washington, DC, p 167-182

Kirst GO, Thiel C, Nothnagel J, Wanzek M, Ulmke R (1991) Dimethylsulfoniopropionate (DMSP) in ice algae and its possible biological role. Mar Chem 35:381-388

Klein B, LeBlanc B, Mei ZP, Beret R and 12 others (2002) Sizefractionated phytoplankton biomass and primary production in the North Water. Deep-Sea Res II 49:4983-5002

Kwint RLJ, Irigoien X, Kramer KJM (1996) Copepods and DMSP. In: Kiene RP, Visscher PT, Keller MD, Kirst GO (eds) Biological and environmental chemistry of DMSP and related sulfonium compounds. Plenum Press, New York, p 239-252

Leck C, Larsson U, Bågander LE, Johansson S, Hajdu S (1990) Dimethyl sulfide in the Baltic Sea: annual variability in relation to biological activity. J Geophys Res C Oceans 95: 3353-3363

Lee PA (1999) Interactions impliquant le sulfure de diméthyle et le sulfoxyde de diméthyle dans le milieu marin. PhD thesis, Université du Québec à Rimouski, Québec

Lee PA, de Mora SJ (1996) DMSP, DMS and DMSO concentrations and temporal trends in marine waters at Leigh, New Zealand. In: Kiene RP, Visscher PT, Keller MD, Kirst GO (eds) Biological and environmental chemistry of DMSP and related sulfonium compounds. Plenum Press, New York, p 391-404

Lee PA, de Mora SJ (1999) Intracellular DMSO in unicellular marine organisms: speculations on its origin and possible biological role. J Phycol 35:8-18

Lee PA, Haase R, de Mora SJ, Chanut JP, Gosselin M (1999) Dimethylsulfoxide (DMSO) and related sulfur compounds in the Saguenay Fjord, Québec. Can J Fish Aquat Sci 56: 1631-1638

Lee PA, de Mora SJ, Gosselin M, Levasseur M, Bouillon RC, Nozais C, Michel C (2001) Particulate dimethylsulfoxide in Arctic sea-ice algal communities: the cryoprotectant hypothesis revisited. J Phycol 37:488-499

Levasseur M, Keller MD, Bonneau E, D'Amours D, Bellows WK (1994) Oceanographic basis of a DMS-related atlantic cod (Gadus morhua) fishery problem: blackberry feed. Can J Fish Aquat Sci 51:881-889

Lewis EL, Ponton D, Legendre L, LeBlanc B (1996) Springtime sensible heat, nutrients and phytoplankton in the North Water polynya, Canadian Arctic. Contin Shelf Res 16:1775-1792 
Lovejoy C, Legendre L, Martineau MJ, Bâcle J, von Quillfeldt $\mathrm{CH}$ (2002) Distribution of phytoplankton and other protists in the North Water. Deep-Sea Res II 49:5027-5047

Malin G, Kirst GO (1997) Algal production of dimethylsulfide and its atmospheric role. J Phycol 33:889-896

Malin G, Turner SM, Liss PS (1992) Sulfur: the plankton/ climate connection. J Phycol 28:590-597

Matrai PA, Keller MD (1993) Dimethylsulfide in a large-scale coccolithophore bloom in the Gulf of Maine. Contin Shelf Res 13:832-843

Melling H, Gratton Y, Ingram G (2001) Ocean circulation within the North Water Polynya of Baffin Bay. AtmosOcean 39:301-325

Mészáros E (1988) On the possible role of the biosphere in the control of atmospheric clouds and precipitation. Atmos Environ 22:423-424

Miller LA, Yager PL, Erickson KA, Amiel D, Bâcle J and 8 others (2002) Carbon distributions and fluxes in the North Water, 1998 and 1999. Deep-Sea Res II 49:5151-5170

Mysak LA, Huang F (1992) A latent- and sensible-heat polynya model for the North Water, Northern Baffin Bay. J Phys Oceanogr 22:596-608

Odate T, Hirawake T, Kudoh S, Fukuchi M (2002) Temporal and spatial patterns in the surface-water biomass of phytoplankton in the North Water. Deep-Sea Res II 49:4947-4958

Parsons TR, Maita Y, Lalli CM (1984) A manual of chemical and biological methods for seawater analysis. Pergamon Press, Oxford

Savoie DL, Prospero JM (1989) Comparison of oceanic and continental sources of non-sea-salt sulphate over the Pacific Ocean. Nature 339:685-689

Simó R, Grimault JO, Albaigés J (1996) Sequential method for the field determination of nanomolar concentrations of dimethyl sulfoxide in natural waters. Anal Chem 68:1493-1498

Simó R, Hatton AD, Malin G, Liss PS (1998) Particulate dimethylsulfoxide in seawater: production by microplankton. Mar Ecol Prog Ser 167:291-296

Stirling I (1980) The biological importance of polynyas in the Canadian Arctic. Arctic 33:303-315

Editorial responsibility: Fereidoun Rassoulzadegan (Contributing Editor), Villefranche-sur-Mer, France
Tang KW, Dam HG, Visscher PT, Fenn TD (1999) Dimethylsulfoniopropionate (DMSP) in marine copepods and its relation to diet and salinity. Mar Ecol Prog Ser 179:71-79

Tang KW, Fenn, TD, Visscher PT, Dam HG (2000) Regulation of body dimethylsulfoniopropionate (DMSP) content by the copepod Temora longicornis: a test of four mechanisms. Mar Biol 135:749-757

Tang KW, Visscher PT, Dam HG (2001) DMSP-consuming bacteria associated with the calanoid copepod Acartia tonsa (Dana). J Exp Mar Biol Ecol 256:185-198

Tremblay JÉ, Gratton Y, Carmack EC, Payne CD, Price NM (2002) Impact of the large-scale Arctic circulation and the North Water polynya on nutrient inventories in Baffin Bay. J Geophys Res C Oceans 107(C8): DOI 10.1029/2000JC 000595

Turner SM, Malin G, Liss PS, Harbour DS, Holligan PM (1988) The seasonal variation of dimethyl sulfide and dimethylsulfoniopropionate concentrations in nearshore waters. Limnol Oceanogr 33:364-375

Vairavamurthy A, Andreae MO, Iverson RL (1985) Biosynthesis of dimethylsulfide and dimethylpropiothetin by Hymenomonas carterae in relation to sulfur source and salinity variations. Limnol Oceanogr 30:59-70

White RH (1982) Analysis of dimethylsulfonium compounds in marine algae. J Mar Res 40:529-536

Wilson WH, Turner S, Mann NH (1998) Population dynamics of phytoplankton and viruses in a phosphate-limited mesocosm and their effect on DMSP and DMS production. Estuar Coast Shelf Sci 46:49-59

Wolfe GV, Steinke M (1996) Grazing-activated production of dimethyl sulfide (DMS) by two clones of Emiliania huxleyi. Limnol Oceanogr 41:1151-1160

Wolfe GV, Steinke M, Kirst GO (1997) Grazing-activated chemical defence in a unicellular marine alga. Nature 387 : 894-897

Zeyer J, Eicher P, Wakeham SG, Schwarzenbach RP (1987) Oxidation of dimethyl sulfide to dimethyl sulfoxide by phototrophic purple bacteria. Appl Environ Microbiol 53: 2026-2032

Submitted: January 14, 2002; Accepted: December 10, 2002 Proofs received from author(s): May 26, 2003 